\title{
Ischemic Priapism Management at the University Hospital, Brazzaville
}

\author{
Rolland Bertille Banga Mouss, Aristd Stève Ondziel Opara, Armel Melvin Ondongo Atipo, \\ Junior Joseph Damba, Yannick I. Dimi Nyanga, Daniela Glore Ngassiele, Mathias Andzin, \\ Anani Wencesl Séverin Odzébé*, Prosper Alain Bouya
}

Brazzaville, Congo

Email: *odzebe_s@yahoo.fr

How to cite this paper: Banga Mouss, R.B., Ondziel Opara, A.S., Ondongo Atipo, A.M., Damba, J.J., Dimi Nyanga, Y.I., Ngassiele, D.G., Andzin, M., Odzébé, A.W.S. and Bouya, P.A. (2021) Ischemic Priapism Management at the University Hospital, Brazzaville. Open Journal of Urology, 11, 458-465.

https://doi.org/10.4236/oju.2021.1112046

Received: September 8, 2021

Accepted: December 12, 2021

Published: December 15, 2021

Copyright $\odot 2021$ by author(s) and Scientific Research Publishing Inc. This work is licensed under the Creative Commons Attribution International License (CC BY 4.0).

http://creativecommons.org/licenses/by/4.0/ (c) (i) Open Access

\begin{abstract}
Background: Priapism is defined as a prolonged and painful erection that persists beyond or is unrelated to sexual stimulation. Its frequency is high in sickle cell patients in our regions. Despite being a urological emergency, many patients are diagnosed at a late stage, increasing their risk of sequelae. In this article, we assessed the management of priapism in our department, with the aim of improving our daily clinical practices. Patients and Methods: We conducted a monocentric retrospective descriptive study from January 2005 to December 2020. All patients admitted and treated for priapism in our emergency department during the study period were included. The following variables were considered: age, sex, etiology, consultation delay, treatment type and outcomes. A follow-up visit was scheduled once at 1, 6 and 12 months post-treatment and the erectile function was evaluated during this visit. Results: In total 97 patients were treated during the study period. Priapism represented the $4^{\text {th }}$ urological emergency after urinary retention, renal colic and hematuria. The mean age was $23.63 \pm 11.5$ years old. Sickle cell disease was observed in $59.8 \%$ of patients. Sixteen patients $(16.50 \%)$ who consulted within 12 hours of priapism onset were successfully treated by oral or injectable etilefrine. Forty-three patients (44.33\%) who consulted between 12 and 36 hours were successfully treated using distal spongio-cavernous fistula. After treatment, detumescence was obtained in 86 patients (88.66\%). Eleven patients (11.34\%), who consulted after the 36th hour, developed cavernous fibrosis with subsequent erectile dysfunction. Conclusion: Priapism represents the $4^{\text {th }}$ cause of admission at our emergency department. Sickle cell disease was the main cause of ischemic priapism in our context. One patient in 2 consulted after 36 hours following the onset of symptoms. Medical treatment was effective in patients who consulted before 12 hours, while surgical treatment resulted in good outcomes in most of the patients who consulted after 36 hours.
\end{abstract}




\section{Keywords}

Priapism, Urological Emergency, Sickle Cell, Caverno-Spongy Shunt

\section{Introduction}

Priapism is defined as a persistent and painful erection for more than 4 hours, occurring without sexual stimulation [1]. Priapism is one of the most common emergencies managed by urologists [2] [3]. Pathophysiological mechanism distinguishes 2 types of priapism: ischemic and non-ischemic priapism [1] [4]. Non-ischemic priapism is rare and mainly associated with perineal trauma. Ischemic priapism, commonly considered as low flow priapism, is the most frequent, often idiopathic, but usually related to sickle cell disease [1]. Ischemic priapism requires urgent treatment to prevent the occurrence of fibrosis and subsequent erectile dysfunction [5]. However, patients with sickle cell disease have shown limited knowledge of this urological emergency, often leading to delayed consultation [6]. In this article, we assessed the management of priapism in our department, with the aim of improving our daily clinical practices.

\section{Patients and Methods}

We conducted a monocentric retrospective descriptive study, at the urology-andrology department of the University Teaching Hospital of Brazzaville over a period of fifteen years (January 2005 to December 2020). All patients admitted for priapism management during this period were included. Data were extracted from patient's medical records. Study variables were age, etiological factors, circumstances of occurrence, consultation delay, type of treatment and outcomes. Patients were seen once at 1, 6 and 12 months after treatment. An assessment of the quality of erectile function was carried out during consultations. To assess the erectile function, we verified during the clinical interview the presence of morning/night erections in pediatric patients and the existence of erections allowing satisfactory sexual intercourse in adults. Patients who reported erectile dysfunction underwent objective complementary exams (pharmaco-induced erection test by intracavernous injection of alprostadil or penile pharmacoechodoppler). The data were entered and processed in the Epi info software version 7.1.3. We used Microsoft Excel for the design of tables and figures. Quantitative variables were expressed as mean ( \pm standard deviation) and qualitative variables as number or percentage.

\section{Results}

In total, 97 patients were admitted to the urology-andrology emergency department for priapism. Priapism prevalence was $1.41 \%$. Priapism was the fourth urological emergency after acute urinary retention, renal colic and hematuria. The mean age was $23.63 \pm 11.5$ years. Table 1 displays distribution by age group. 
Table 1. Distribution of patients according to age groups.

\begin{tabular}{ccc}
\hline & $\mathbf{n}$ & $\%$ \\
\hline$<10$ & 8 & 8.25 \\
{$[10-19]$} & 29 & 29.9 \\
{$[20-29]$} & 24 & 24.74 \\
{$[30-39]$} & 25 & 25.77 \\
{$[40-49]$} & 6 & 6.19 \\
$>49$ & 5 & 5.15 \\
Total & 97 & 100 \\
\hline
\end{tabular}

Thirty-five patients $(36.08 \%)$ had a history of priapism. Among them, 24 patients $(24.74 \%)$ had at least two past episodes of priapism. Twenty-one patients had previously been hospitalized and 14 patients had intermittent priapism episodes. Medical comorbidities such as hypertension and diabetes were found in 3 and 4 patients respectively. The circumstances of priapism occurrence are reported in Figure 1. Sixteen patients (16.50\%) came to our emergency department within 12 hours from the onset of symptoms, 43 patients (44.33\%) between 12 and 36 hours, and 38 patients (39.17\%) after 36 hours.

Table 2 shows the main causes of priapism in our study. Fifty-one patients (52.58\%) had homozygous SS sickle cell disease and 7.22\% had heterozygous AS sickle cell disease. Among these patients, 32 (33\%) had severe anemia that required blood transfusion.

Table 3 presents the different treatment modalities. Figure 2 shows the delay of the occurrence of detumescence after treatment. After treatment, detumescence was obtained in 86 patients $(88.66 \%)$. Medical treatment had been effective in patients admitted before the $12^{\text {th }}$ hour. Between 12 and 36 hours, surgical treatment was performed, and it was effective in all patients. However, in patients admitted after 36 hours, surgery was effective in $71.05 \%$ of cases $(n=27)$ only. Eleven patients (11.34\%) developed cavernosal fibrosis with subsequent erectile dysfunction.

\section{Discussion}

Priapism prevalence remains difficult to assess in our countries. In this study, priapism prevalence was estimated at $1.41 \%$ (97 patients in total). An earlier study conducted at our department reported discordant results. In fact, Bouya et al. found 32 cases of priapism due to sickle cell disease, over a period of 11 years, with an average of 3 cases per year [7]. Similarly, fall in Senegal [8] reported 63 cases in 20 years (3.15 cases per year). In 2017, a referral center for sickle disease management was implemented at the university hospital center of Brazzaville. The referral center did not exist when Bouya et al. conducted their study. This could explain the increased number of patients seen in our urology emergency department during our study period. 
Table 2. Distribution of patients according to etiological factors.

\begin{tabular}{ccc}
\hline & $\mathbf{n}$ & $\%$ \\
\hline Sickle cell anemia & 58 & 59.80 \\
Intra Cavernous Injection of Erectogenic Drugs & 4 & 4.12 \\
Oral aphrodisiacs & 2 & 2.06 \\
Leukemia & 1 & 1.03 \\
Polycythemia & 2 & 2.06 \\
Idiopathic causes & 30 & 30.93 \\
Total & $\mathbf{9 7}$ & 100 \\
\hline
\end{tabular}

Table 3. Presentation by type of treatment.

\begin{tabular}{cccc}
\hline & \multicolumn{2}{c}{ Medical treatment } & \\
\cline { 2 - 3 } Surgical treatment & $\begin{array}{c}\text { Puncture of the penis } \\
\text { corpus cavernosum } \\
\text { and Etilefrine }\end{array}$ & None & Total \\
\hline Proximal cavernosa-spongosium shunt (1) & 0 & 0 & 0 \\
Distal cavernosa-spongosium shunt (2) & 25 & 41 & $\mathbf{6 6}$ \\
$1+2$ & 12 & 01 & 13 \\
None & 18 & 0 & $\mathbf{1 8}$ \\
Total & 55 & $\mathbf{4 2}$ & $\mathbf{9 7}$ \\
\hline
\end{tabular}

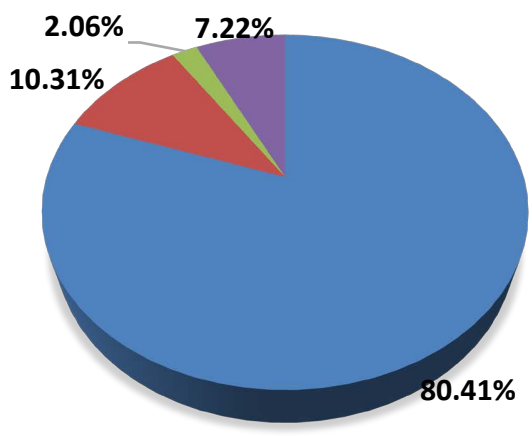

\section{- Spontaneously \\ During masturbation}

Figure 1. installation mode priapism.

Ischemic priapism mostly affects young patients in countries where sickle cell disease is endemic [7] [8] [9] [10] [11]. The first episode usually occurs at the age of 10 years old [12] [13] [14]. Despite the acute pain which characterizes ischemic priapism, many patients still present themselves many hours following the beginning of symptoms. While it is well established that early diagnosis and management is associated with reduction of erectile dysfunction sequelae and better prognosis, the reluctance in consultation in our context could be explained 


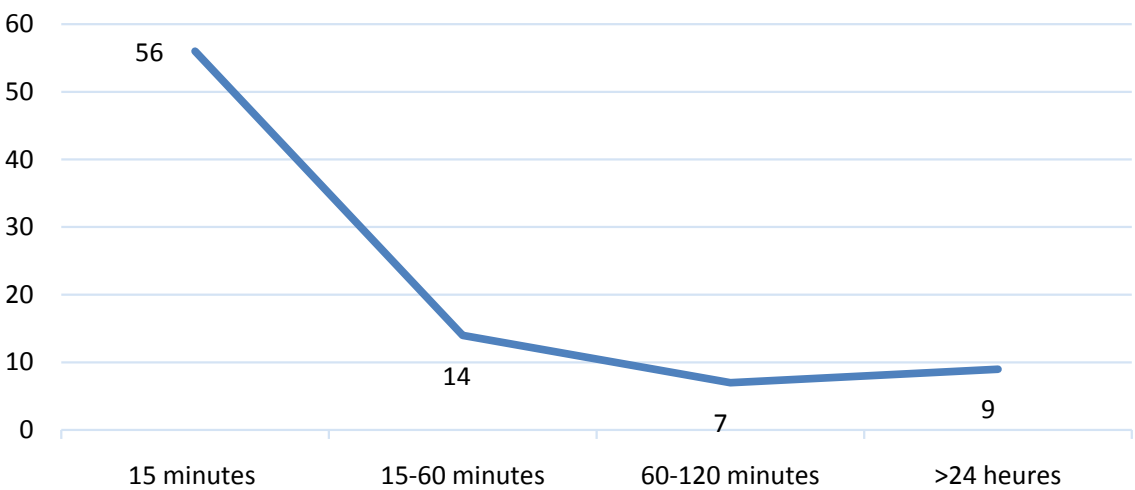

Figure 2. Detumescence time after treatment.

by many reasons such as ignorance of existing therapeutic modalities, taboos surrounding sexuality, low socioeconomic status, lack of healthcare facilities or insufficient trained urologists [7] [8].

Priapism occurs in two forms:

- The acute form is the best known. It gives spontaneously a persistent and painful erection that can lead to erectile dysfunction.

- And the chronic form, commonly called chronic intermittent priapism (PIC) or stuttering priapism is characterized by repeated episodes of nocturnal short term that may extend over several months or years despite treatment. Very few described in the literature, the PIC seems nevertheless more common than acute priapism [15].

Both forms are in fact only forms of low flow or ischemic priapism.

Priapism most often occurs spontaneously and during sleep. Nowadays, the use of erectogenic drugs contributes significantly to the occurrence of priapism [7].

Several studies reported high rates of sickle cell disease patients in the group of patients with priapism. These are mainly the results of studies carried out in areas where sickle cell disease is endemic [7] [8] [16]. Sickle cell disease plays a central role in the mechanisms by which priapism occurs. While anatomic factors and a low-flow state contribute to making erectile tissue prone to sickle cell-induced pain and ischemia, abnormal regulation of the nitric oxide pathway and its downstream signaling may be particularly key in the development of priapism and other vascular complications in sickle cell disease [17].

In our study, medication intake was the $3^{\text {rd }}$ cause of ischemic priapism, after idiopathic causes. These medications were dominated by intracavernous injections of erectogenic drugs. Our findings are in contrast with studies conducted in developed countries, in which erectogenic medication intake represented the main cause of priapism [16] [18] [19] [20]. As it is reported in the literature, ischemic priapism is also due to others causes such as antipsychotics, neuroleptic or pulmonary infections [8] [21] [22] [23]. We did not find such causes in our study.

Treatment modalities depend on 2 factors: the incriminated pathophysiologi- 
cal mechanism (ischemic versus non ischemic priapism) and the time delay between onset of symptoms and management [24] [25] [26] [27]. In fact, priapism is an urological emergency that requires a prompt consultation, and its treatment must be done early (in the first hours) in order to obtain successful results. However, ischemic priapism due to sickle cell disease usually has a good prognosis even when treated later, as reported by Bouya et al. [7] in his study. There is no standard medical procedure for ischemic priapism treatment. In our study, medical treatment was used as a first line treatment in young sickle cell patients for up to 24 hours. Medical treatment consisted of corporal aspiration and/or injection of sympathomimetics. Detumescence was achieved in 18 patients treated medically, while 43 patients had unsuccessful results with the medical treatment. These patients were successfully treated with surgical procedure [28].

Our study reports satisfactory results in patients who had consulted before the $12^{\text {th }}$ hour. Surgical treatment was used successfully in all patients who consulted between 12 and 36 hours. Of the 38 patients who consulted after the 36th hour, 27 patients or $71.05 \%$ had reported good results. Distal cavernosa-spongosium shunt was the first-line surgical treatment technique. This technique gave $68 \%$ of satisfactory results. Proximal cavernosa-spongosium was the second-line technique used when the first one failed. Despite a relatively long delay of consultation prior to priapism treatment, $88.66 \%$ of patients consider having a satisfactory erection.

Our study has several limitations. First, this was a snapshot of priapism management based on hospital data. It is well known that some patients don't come to the hospital, especially when it concerns the male genital organ. Therefore, the priapism prevalence reported in this study may have been underestimated. Second, erectile function was difficult to assess during consultation. In fact, male genital organ diseases are still taboo in our context, and patients may seem reluctant to answer questions on their sexual function. Thus, it is not excluded that many patients provided inaccurate responses regarding their erections during sexual intercourse, leading to a possible information bias. Similarly, evaluating the quality of erections in pediatric patients by interviewing their parents was made difficult because of the same taboo mentioned previously. Third, IIEF5 questionnaires were not routinely used for many reasons: questionnaires being too long according to patients, items difficult to understand especially in patients with low education level.

\section{Conclusion}

Priapism is a rare emergency in urology. In our countries, sickle cell disease represents the main cause, followed by idiopathic causes. Many patients are still admitted in urology after the 36th hour. Surgical treatment provides good results especially when patients are seen earlier.

\section{Conflicts of Interest}

The authors declare no conflicts of interest regarding the publication of this paper. 


\section{References}

[1] Carnicelli, D. and Akakpo, W. (2018) Priapism: Diagnosis and Management. Progrès en Urologie, 28, 772-776. https://doi.org/10.1016/j.purol.2018.07.281

[2] Carvajal, A. and Benavides, J.A. (2019) Combination High Flow Priapism with Low Flow Priapism: Case Report. Sexual Medicine, 7, 111-113. https://doi.org/10.1016/j.esxm.2018.10.003

[3] Gravel, J., Le Blanc, C. and Varner, C. (2019) Management of Priapism with a Trial of Exercise in the Emergency Department. CJEM, 21, 150-153. https://doi.org/10.1017/cem.2018.3

[4] Kumar, P., Rahman, K., Kumari, S., Singh, M.K., Gupta, R. and Nityanand, S. (2018) Priapism as a Rare Presentation of Chronic Myeloid Leukemia. Journal of Cancer Research and Therapeutics, 14, 1442-1443. https://doi.org/10.4103/0973-1482.199388

[5] Habou, O., Adamou, H., Magagi, I.A., Amadou, S., Magagi, A., Bade, A.M., Sanda, O.G. and Abarchi, H. (2017) Management of Acute Ischemic Priapism at National Hospital Lamordé of Niamey. African Journal of Urology, 23, 338-341. https://doi.org/10.1016/j.afju.2017.03.003

[6] Elira, D.A. and Nzingoula, S. (2003) Clinical Profile of Sickle Cell Homozygous Individual after the Age of 30. Tunisie Médicale, 81, 101-108.

[7] Bouya, P.A., Odzébé, A.W.S., Koumou Moritoua, R.D. and Elira Dokékias, A. (2011) Acute Sickle Cell Priapism: Analysis of 20 Cases Treated at the University Hospital of Brazzaville. Andrologie, 21, 34-37. https://doi.org/10.1007/s12610-010-0110-3

[8] Fall, P.A., Diao, B., Ndoye, A.K., Ndiaye Diop, E., Sylla, C., Gueye, S.M. and Diagne, B.A. (2005) Priapism: Clinical Aspects and Etiology. African Journal of Urology, 11, 186-190.

[9] Sadeghi-Nejad, H., Dogra, V., Seftel, A.D. and Mohamed, M.A. (2004) Priapism. Radiologic Clinics of North America, 42, 427-443. https://doi.org/10.1016/j.rcl.2004.01.008

[10] Droupy, S. and Giuliano, F. (2013) Priapism. Progrès en Urologie, 23, 638-646. https://doi.org/10.1016/j.purol.2013.01.026

[11] Nandiolo-Anelone, K.R., Djè, K., Bankolé, S.R. and Mobiot, M.L. (2011) Prise en charge du priapisme chez l'enfant au CHU de Treichville. African Journal of Urology, 17, 59-65. https://doi.org/10.1007/s12301-011-0012-4

[12] Okoko, A.R., Odzébé, A.S.W., Moyen, E., Ekouya Bowassa, G., Oko, A.P.G., Mbika-Cardorelle, A., Bozock, P., Atanda, H.L. and Moyen, G.M. (2014) Priapism in Children and Adolescents Homozygous Sickle Cell Disease in Brazzaville. Progrès en Urologie, 24, 57-61. https://doi.org/10.1016/j.purol.2013.04.021

[13] Gbadoé, A.D., Dogba, A., Ségbéna, A.Y., Nyadanu, M., Atakouma, Y., Kusiaku, K., Vovor, A. and Assimadi, J.K. (2001) Priapism in Sickle Cell Anemia in Togo: Prevalence and Knowledge of This Complication. International Journal for Hemoglobin Research, 25, 355-361. https://doi.org/10.1081/HEM-100107871

[14] Mantadakis, E., Cavender, J.D., Rogers, Z.R., Ewalt, D.H. and Buchanan, G.R. (1999) Prevalence of Priapism in Children and Adolescents with Sickle Cell Anemia. Journal of Pediatric Hematology/ Oncology, 21, 518-522. https://doi.org/10.1097/00043426-199911000-00013

[15] Gbadoé, A.D., Koffi, K.S., Akakpo-Maxwell, O., Lawson-Évi, K., Guédéhoussou, T. and Kossi Assimadi, J. (2002) Prise en charge du priapisme drépanocytaire par 
médications alpha-adrénergiques. Cahiers d'études et de recherches francophones / Santé, 12, 343-347.

[16] Virag, R., Bachir, D., Floreslo, J., Galacteros, F. and Dufour, B. (1997) Le priapisme à propos de 172 cas. Annal d' urologie, 121, 642-652.

[17] Crane, G.M. and Bennett Jr., N.E. (2011) Priapism in Sickle Cell Anemia: Emerging Mechanistic Understanding and Better Preventative Strategies. Anemia, 2011, Article ID: 297364. https://doi.org/10.1155/2011/297364

[18] Portillo Martin, J.A., Correas Gomez, M.A., Gutiérrez Banos, J.L., Martín García, B., Hernández Rodríguez, R., Valle Schaan, J.I.D., et al. (2001) Incidence of Priapism at the Marqués de Valdecilla University Hospital. Archivos Españoles de Urología, 54, 241-246.

[19] Perimenis, P., Athanasopoulos, A., Germoutsos, I. and Barbalias, G. (2001) The Incidence of Pharmacologically Induced Priapism in the Diagnostic and Therapeutic Management of 685 Men with Erectile Dysfunction. Urologia Internationalis, 66, 27-29. https://doi.org/10.1159/000056558

[20] Keskin, D., Cal, C., Delibas, M., Ozyurt, C., Günaydin, G., Nazli, O. and Cüreklibatir, I. (2000) Intracavernosal Adrenalin Injection in Priapism. International Journal of Impotence Research, 12, 312-314. https://doi.org/10.1038/sj.ijir.3900539

[21] Brichart, N., Delavierre, D., Peneau, M., Ibrahim, H. and Mallek, A. (2008) Priapism Associated with Antipsychotic Medications: A Series of Four Patients. Progrès en Urologie, 18, 669-673. https://doi.org/10.1016/j.purol.2008.04.010

[22] Doufik, J., Otheman, Y., Khalili, L., Ghanmi, J. and Ouanass, A. (2014) Antipsychotic-Induced Priapism and Management Challenges: A Case Report. L'encéphale, 40, 518-521. https://doi.org/10.1016/j.encep.2013.11.004

[23] Sibai, H., Sakoute, A., yaakoubi, M. and Fehri, M. (2003) Pediatric Priapism Associated with Pulmonary Infection. Annales Urologie, 37, 143-145.

https://doi.org/10.1016/S0003-4401(03)00048-2

[24] Bondil, P., Descottes, J.L., Salti, A., Sabbagh, R. and Hamza, T. (1997) Conservative Treatment of Venous Priapism Based on a Series of 46 Cases: Puncture, Pharmacological Detumescence or Penile Cooling? Progrès en Urologie, 7, 433-441.

[25] Broderick, G.A., Kadioglu, A., Bivalacqua, T.J., Ghanem, H., Nehra, A. and Shamloul, R. (2010) Priapism: Pathogenesis, Epidemiology, and Management. The Journal of Sexual Medicine, 7, 476-500. https://doi.org/10.1111/j.1743-6109.2009.01625.x

[26] Huang, Y.C., Harraz, A.M., Shindel, A.W. and Lue, T.F. (2009) Evaluation and Management of Priapism: 2009 Update. Nature Reviews Urology, 6, 262-271. https://doi.org/10.1038/nrurol.2009.50

[27] Salonia, A., Eardley, I., Giuliano, F., Hatzichristou, D., Moncada, I., Vardi, Y., et al. (2014) European Association of Urology Guidelines on Priapism. European Urology, 65, 480-489. https://doi.org/10.1016/j.eururo.2013.11.008

[28] Kamel, K., Mohamed, M., Abderrazek, B., Mohamed, C., Amine, D., Riadh, B.S., et al. (2016) Delayed Management of Low-Flow Priapism: About 28 Cases. African Journal of Urology, 22, 297-304. https://doi.org/10.1016/j.afju.2015.10.005 